\title{
Circuit
}

Musiques contemporaines

\section{« L’autre Gould » en baladodiffusion}

Volume 25, numéro 1, 2015

URI : https://id.erudit.org/iderudit/1029478ar

DOI : https://doi.org/10.7202/1029478ar

Aller au sommaire du numéro

Éditeur(s)

Les Presses de l’Université de Montréal

ISSN

1183-1693 (imprimé)

1488-9692 (numérique)

Découvrir la revue

Citer ce document

(2015). « L'autre Gould » en baladodiffusion. Circuit, 25(1), 75-75.

https://doi.org/10.7202/1029478ar

Ce document est protégé par la loi sur le droit d'auteur. L'utilisation des services d'Érudit (y compris la reproduction) est assujettie à sa politique d'utilisation que vous pouvez consulter en ligne.

https://apropos.erudit.org/fr/usagers/politique-dutilisation/
Cet article est diffusé et préservé par Érudit.

Érudit est un consortium interuniversitaire sans but lucratif composé de l'Université de Montréal, l'Université Laval et l'Université du Québec à Montréal. Il a pour mission la promotion et la valorisation de la recherche. https://www.erudit.org/fr/ 


\section{«L'autre Gould» en baladodiffusion}
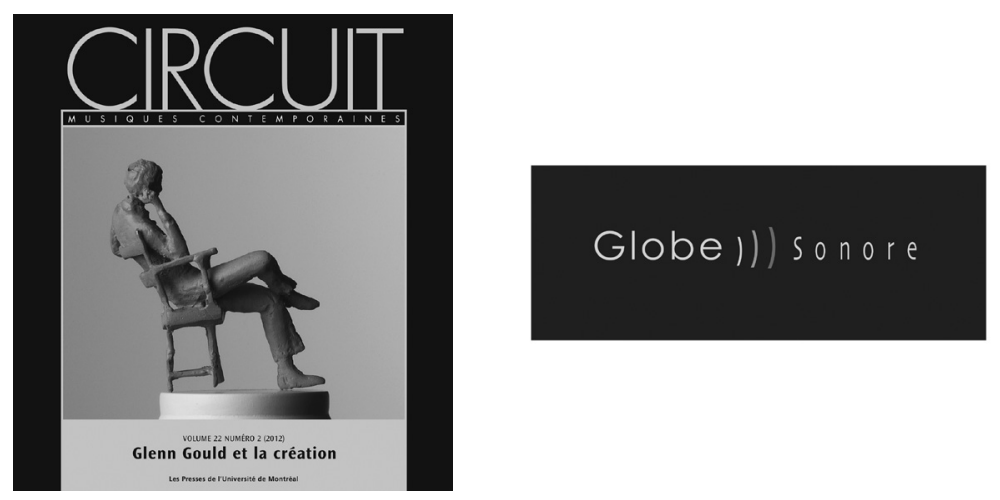

Document sonore disponible en ligne sur le site web de Globe sonore: www.globesonore.org

Depuis 2014, Circuit, en partenariat avec la revue Intermédialités, se lance dans la production de balados (podcasts) avec la série Contrepoints, diffusée sur la web radio Globe sonore.

Paru en juin 2014, le premier opus, intitulé «La musique des objets », s'inspirait des textes parus dans le vol. 23, n 1 (2013) de Circuit, qui portait le même nom, mais en l'illustrant de nombreux extraits sonores d'œuvres de Martin Messier (à qui l'on doit également l'indicatif de la série), du groupe Sonde, de Jean-François Laporte, de Magali Babin et de Nicolas Bernier, ce dernier ayant, en outre, accepté de prêter également sa voix à notre production.

Le dernier opus, «Lautre Gould», reprend la même formule en s'appuyant sur des textes issus du vol. 22, $\mathrm{n}^{\circ} 2$ (2012) de Circuit, ainsi que du matériel publié dans Intermédialités ( $\mathrm{n}^{\text {os }} 19$ et 20, 2012). Les textes, ponctués également d'extraits sonores, permettent de découvrir non plus Gould l'interprète, mais l'«autre Gould», le créateur d'œuvres radiophoniques telles que la Solitude Trilogy. En outre, le balado présente la pièce de Mario Gauthier, Point contre point (2012), un essai audio réalisé par l'artiste pour Intermédialités et à partir du Radio as Music de Gould.

Bonne écoute!

Réalisation: Solenn Hellégouarch et Pierre Lavoie, avec la participation de Jonathan Goldman et Philippe Despoix. 